\title{
Late effects of manual therapy techniques on the flexibility and electrical activity of antigravitational muscles
}

\author{
Ferreira K Maracaja ${ }^{1}$, Lins M Silva ${ }^{1}$, Souza M Mota ${ }^{1}$, Rodrigues MR Alves ${ }^{1}$ and Bakke O Alves ${ }^{2}$ \\ ${ }^{1}$ Faculdades Integradas de Patos, Itapetim, PE, Brazil \\ ${ }^{2}$ San Carlos University, Paraguay, Patos, PB, Brazil
}

\begin{abstract}
Introduction: Flexibility is the potential that the joint can perform of full range or movement, without having any inflammatory process, pain or blockage. Several techniques have been used in order to optimize it. However, very little is known about the evidence on the late effects of flexibility gain techniques, electromyographic effects after the use of these techniques and which technique would be most suitable for this purpose.

Objective: This study aimed to analyze the late effects of different manual therapy techniques on the flexibility and electromyographic signal of antigravity muscles.

Theoretical framework: The study is a clinical trial, with 80 subjects subdivided into 4 groups: Group 1 (G1) was submitted to High Velocity Low Amplitude (HVLA) thrust technique. Group 2 (G2) was submitted to Muscular Energy Technique (MET). Group 3 (G3) was submitted to Neural Mobilization (NM). Group 4 or Control Group (CG) was at rest. All subjects were evaluated immediately before and one day after (late) intervention. The flexibility of the antigravitational muscles and the electromyographic activity of the multifidus muscles at rest and in the maximal voluntary isometric contraction were evaluated.

Results: The NM and MET technique produced a significant increase in the flexibility of the antigravity muscles. The electromyographic signal presented no significant difference after the interventions.

Conclusion: The flexibility of the antigravitational muscles showed a significant increase after the use of HVLA technique, MET, NM techinique, and rest, observed late, in the subjects of the present study. However, the electromyographic activity of the multifidus muscles did not undergo significant changes after the manual techniques used.
\end{abstract}

\section{Introduction}

The movement of the human body is a complex system of levers and fulcrums where external and internal forces act, one overlapping the other. The locomotor system leads to the internal force originating from muscular action, since the force of gravity, aerodynamic resistance and hydrodynamics, are external forces that participate in the movement, either in aid or opposition [1].

The reduction or incapacity of this movement can be provoked by the most diverse pathologies. They concomitantly affect the psychic, organic nature of the individual progressing to kinetic-functional disorder with impairment to daily life activities (DLAs) [2].

The human body has movement as its main function. If there are changes in the motor limits, you can reduce joint flexibility. Its adequate performance depends closely on the anatomical integrity of tendons, ligaments and joint capsules, as well as endogenous factors related to age and gender [3].

Changes in range of motion are due to muscular changes that occur throughout life, since there is a numerical decrease of sarcomeres in series, and because they are distant from their anatomical length, they lose the contraction power reducing their main physiological property. Harmful effects to the range of motion would be muscle shortening $[4,5]$.

The MET is capable of increasing flexibility, since with isometric contractions in sequence, activation of the Golgi Tendon Organs and progressive inhibition of the Neuromuscular Spindle is achieved, preventing the alpha and beta motoneurons from acting, facilitating the post-isometric relaxation and favoring the increase in muscle length [6].

HVLA, commonly used by chiropractors, physiotherapists and osteopaths, has a favorable effect on musculoskeletal dysfunction, bringing benefits by restoring the biomechanics of the synovial joint, restoring normal mobility $[7,8]$. It aids in the disorders presented in the axial skeleton. The technique is based on the application of force in a joint segment of the spine in the direction previously determined by the therapist. It is common to hear during the maneuver the thrust that is proper to joint cavitation [9].

Another therapy used to restore flexibility is NM. The technique consists in positioning the patient so that the posture adopted exerts a tension. Then he asks the patient to perform joint oscillations in the tension direction [10].

Surface electromyography (SEMG) is a suitable instrument for the verification of the muscular electrical signal [11]. The use of surface electromyography (SEMG) in university students with

${ }^{\star}$ Correspondence to: Souza M Mota, Faculdades Integradas de Patos: João Pessoa, PB, Brazil, E-mail: maerciomota@bol.com.br

Key words: electromyography, flexibility, muscle stretching exercise, osteopathic manipulation, neural inhibition

Received: February 14, 2019; Accepted: March 08, 2019; Published: March 12 2019 
Temporomandibular Dysfunction (TMD), can observe the increase of the electromyographic signal during the maximum voluntary isometric contraction of the masseter after chiropractic use in the temporomandibular joint [12].

It was also observed an increase in the electromyographic activity in the right and left anterior tibial muscles, after neural mobilization of the lumbosacral roots, and the sciatic nerve with emphasis to the fibular nerve in patients with leprosy [13].

Unlike the other techniques mentioned above, MET with postisometric relaxation has decreased electromyographic activity, contributing to the joint range of motion (ROM) gain and potentiating the flexibility of muscle tissue [14].

It is extremely important to point out that muscle elastic deficiency is a deleterious factor for the individual's functional performance, predisposing him to the appearance of future musculo-tendineal lesions [15-17].

There is a gap in studies on the effects of techniques in manual therapy: What manual therapy techniques can promote increased flexibility and consequently range of motion, while promoting the reduction of myoelectric activity (muscle relaxation), with late effects? The objective of this research was to analyze the late effect of manual therapeutic techniques on flexibility and myocyte electrical activity of antigravity muscles.

\section{Materials and methods}

This study was carried out in accordance with Resolution 466/2012, which indicates guidelines and norms of research involving human beings in Brazilian territory. The research protocol was approved by the Research Ethics Committee of the Faculdades Integradas de Patos, no. 39748714.9.0000.5181. The subjects who participated in the research signed the Free and Informed Consent Term.

It was a randomized clinical trial that was conducted between July and October 2015, in the premises of the Dr Aderban Martins de Medeiros Clinical School of Physiotherapy, Faculdades Integradas de Patos-PB.

The criteria we used to seal the participants of the research were: to be 18 years of age or older and no history of musculoskeletal symptoms in the week prior to study participation. The exclusion criterion adopted was presence of pathology or severe deformities of the musculoskeletal system that disables participation in the study or absence of during the period of data collection.

We selected 80 subjects, among a population constituted by 273 students of the physiotherapy course. Of the selected, 46 were women and 34 were men, aged between 18 and 29 years. Each group was allocated in 4 different groups: 20 subjects were grouped in group 1 (G1 - HVLA), 20 subjects in group 2 (G2 - MET), 20 subjects in group 3 (G3 - NM) and 20 subjects in the control group.

\section{Instruments and procedures for data collection (pre and post-intervention evaluation)}

To assess flexibility, the data collection instrument used was the Wells Bank, with the sit-and-reach test, to measure the flexibility of the antigravitational muscles of the subjects surveyed. Participants' flexibility was measured on a scale in centimeters (present at the Wells Bank) during the test run [18].

To obtain the measure of flexibility, each subject performed three times the test, choosing to record the best measure reached in the three trials, that is, the highest numerical value obtained. The flexibility measure was taken immediately before the intervention and one day after the intervention.

The electromyographic signal was captured by means of surface electromyography on the multiphidial muscle group bilaterally. The EMG-800C electromyograph (EMG System do Brasil ${ }^{\circ}$ ) was used with 4 channels, with a plate that transforms 12-bit analog / digital signals, $2000 \mathrm{~Hz}$ sampling, common module greater than $100 \mathrm{~dB}$, noise less than $3 \mu \mathrm{V}$ RMS and impedance of $109 \mathrm{Ohms}$.

The electrodes were placed in the paravertebral region (two on the right and two on the left) to capture the signal multifideo muscle group in L5 and L2. Each electrode was placed between the points marked between the postero-superior iliac spine and the last rib. The individual was kept in the ventral decubitus position and the electrodes were arranged longitudinally. In the spinous process of $\mathrm{C} 7$ another reference electrode was positioned. The area was duly cleaned and tricotomized in each subject. For each individual of all groups, the evaluation of the electrical signal was captured immediately before the intervention and one day after the intervention.

The electrical signal was captured at rest (captured with the subject positioned in the ventral decubitus position) and during isometry of the assessed muscle group. For the latter, the individual was asked to perform maximum effort during trunk extension in the ventral decubitus three times, against the maximum manual resitance of the evaluator at the time of $\mathrm{T} 4$, in order to obtain the highest electromyographic peak during the maximal voluntary isometric contraction of spinal erector. For good stability, the legs of each subject were affixed to the stretcher, using belts for this purpose [19]. The captured electrical signal was recorded grossly and later (during data processing) the values were normalized [20].

\section{The interventions of each group}

Group 1 (subjects submitted to HVLA): The HVLA thrust technique was performed in vertebral segments of the 3rd lumbar vertebra (L3), 9th thoracic vertebra (T9) and 5th cervical vertebra (C5), places of considerable muscular tension in the spinal column because they were located at the apex of the physiological curves. In L3 the Lumbar Roll technique was used, in T9 it was used Dog Technique and in the C5 vertebra Ashmore Technique was used. The techniques were performed bilaterally, in each subject. In all the subjects of the group the maneuvers were applied by the same individual, who was properly trained. The duration of the intervention in each subject submitted to the HVLA techniques was variable (lasting in average 10 minutes), due to the variation of the stature and the weight of each subject.

Group 2 (subjects submitted to MET): MET was applied bilaterally on antigravitational muscles: plantar muscles, leg, thigh and spine. For each muscle technique group was performed as follows: the subject was required an isometric contraction of the target muscle group (contrary to manual resistance imposed by a trained therapist) for a period of 10 seconds, with low strength, followed by a period of a slow post-isometric elongation (performed passively) until reaching the elastic barrier. After this, this cycle was repeated 5 times for each muscle group, with progessive gain of range of motion after each isometric contraction. The duration of the intervention in each subject submitted to the MET was in average 25 minutes.

Group 3 (submitted to NM): The NM technique was applied with the subject in the position of Slump Test. The subject was asked to perform active oscillatory movements (knee flexion and extension, 
oscillating between $45^{\circ}$ and $90^{\circ}$ of knee range) at a frequency of one knee flexion extension per second for one minute. Three sets of 1 minute were performed for each lower limb with 10 second intervals between each series. Then, the same conduct was adopted for the contralateral lower limb. The duration of the intervention in each subject submitted to the NM was in average 7 minutes.

Control group (submitted to rest in dorsal decubitus): subjects remained in supine position without any intervention for one minute.

\section{Statistical analysis}

Statistical analysis was performed by SPSS version 18.0. The mean and standard deviation measures of the flexibility and myoelectric activity variables were obtained with descriptive statistics. The differences between the means were tested with inferential statistics by means of the $t$ test repeated measures.

\section{Results}

Of the 80 participants, $60 \%$ were female and $40 \%$ male, with ages ranging from 18 to 29 years.

Regarding the analysis of the electromyographic signal of the muscles evaluated at rest, before and after intervention, there were no significant statistical differences in any of the groups, as evidenced in table 1.

Table 2 shows that, similarly to previous results, there were no statistically significant differences in the electromyographic signal in isometry of the muscles evaluated.

As for the normalized electromyographic signal of the muscles evaluated at rest, there were no statistically significant differences in any of the groups, as shown in table 3.

According to the normalized electromyographic signal of the muscles in isometry, it could be verified from table 4 that there were no statistically significant differences in any of the groups.

Regarding the flexibility of the antigravitational muscles, HVLA, MET and NM technique produced significant late gains in flexibility. Flexibility gains produced by rest were also statistically significant, as shown in table 5.

\section{Discussion}

The techniques of manual therapy used in the present study promoted an improvement in the flexibility of antigravitational muscles

Table 1. Mean and Standard Deviation of the Electromyographic Signal of Multifidus Muscles Before and After Resting Intervention $(\mathrm{mV})$

\begin{tabular}{|c|c|c|c|c|c|c|}
\hline \multirow{2}{*}{ Group } & \multicolumn{3}{|c|}{ Right } & \multicolumn{3}{c|}{ Left } \\
\cline { 2 - 7 } & Before & After & $\boldsymbol{p}$ & Before & After & $\boldsymbol{p}$ \\
\hline MAAV & $22.5 \pm 16.7$ & $18.1 \pm 6.7$ & 0.2 & $16.5 \pm 10.0$ & $13.5 \pm 5.8$ & 0.2 \\
\hline EM & $14.9 \pm 6.1$ & $14.4 \pm 5.2$ & 0.7 & $11.2 \pm 6.7$ & $10.6 \pm 4.8$ & 0.7 \\
\hline MN & $16.2 \pm 8.3$ & $18.4 \pm 14.7$ & 0.5 & $12.0 \pm 6.9$ & $13.2 \pm 8.6$ & 0.2 \\
\hline GC & $17.6 \pm 4.5$ & $17.9 \pm 4.7$ & 0.3 & $12.9 \pm 4.3$ & $13.2 \pm 4.3$ & 0.4 \\
\hline
\end{tabular}

Table 2. Mean and standard deviation of the electromyographic signal of multifidus muscles before and after isometry intervention $(\mathrm{mV})$

\begin{tabular}{|c|c|c|c|c|c|c|}
\hline Group & \multicolumn{3}{|c|}{ Right } & \multicolumn{3}{c|}{ Left } \\
\hline & Before & After & $\boldsymbol{p}$ & Before & After & $\boldsymbol{p}$ \\
\hline MAAV & $388.6 \pm 193.4$ & $475.2 \pm 259.9$ & 0.06 & $441.7 \pm 264.5$ & $401.2 \pm 199.8$ & 0.3 \\
\hline EM & $380.8 \pm 177.9$ & $353.2 \pm 191.8$ & 0.4 & $401.4 \pm 183.6$ & $413.3 \pm 347.6$ & 0.5 \\
\hline MN & $301.3 \pm 184.7$ & $332.1 \pm 177.8$ & 0.5 & $322.8 \pm 191.9$ & $329.7 \pm 156.7$ & 0.8 \\
\hline GC & $644.6 \pm 396.6$ & $623.3 \pm 360.5$ & 0.1 & $627.6 \pm 349.3$ & $563.1 \pm 294.1$ & 0.1 \\
\hline
\end{tabular}

Table 3. Mean and standard deviation of the normalization of the electromyographic signal of resting multifidus muscles $(\mathrm{mV})$

\begin{tabular}{|c|c|c|c|c|c|c|}
\hline Group & \multicolumn{3}{|c|}{ Right } & \multicolumn{3}{c|}{ Left } \\
\hline & Before & After & $\boldsymbol{P}$ & Before & After & $\boldsymbol{p}$ \\
\hline MAAV & $1.0 \pm 0.0$ & $0.97 \pm 0.8$ & 0.1 & $1.0 \pm 0.0$ & $1.01 \pm 0.4$ & 0.8 \\
\hline EM & $1.0 \pm 0.0$ & $1.23 \pm 1.1$ & 0.3 & $1.0 \pm 0.0$ & $1.16 \pm 0.7$ & 0.3 \\
\hline MN & $1.0 \pm 0.0$ & $1.01 \pm 0.3$ & 0.8 & $1.0 \pm 0.0$ & $1.11 \pm 0.6$ & 0.4 \\
\hline GC & $1.0 \pm 0.0$ & $0.97 \pm 0.3$ & 0.7 & $1.0 \pm 0.0$ & $1.02 \pm 0.16$ & 0.5 \\
\hline
\end{tabular}

Table 4. Mean and standard deviation of the normalization of the electromyographic signal of multifidus muscles in isometry (mv)

\begin{tabular}{|c|c|c|c|c|c|c|}
\hline Group & \multicolumn{3}{|c|}{ Right } & \multicolumn{3}{c|}{ Left } \\
\hline & Before & After & $\boldsymbol{P}$ & Before & After & $\boldsymbol{p}$ \\
\hline MAAV & $1.0 \pm 0.0$ & $1.16 \pm 0.4$ & 0.1 & $1.0 \pm 0.0$ & $0.98 \pm 0.3$ & 0.8 \\
\hline EM & $1.0 \pm 0.0$ & $0.96 \pm 0.5$ & 0.7 & $1.0 \pm 0.0$ & $0.97 \pm 0.4$ & 0.7 \\
\hline MN & $1.0 \pm 0.0$ & $0.96 \pm 0.5$ & 0.7 & $1.0 \pm 0.0$ & $0.97 \pm 0.4$ & 0.7 \\
\hline GC & $1.0 \pm 0.0$ & $1.43 \pm 1.3$ & 0.1 & $1.0 \pm 0.0$ & $1.31 \pm 0.9$ & 0.1 \\
\hline
\end{tabular}

Table 5. Mean and Standard Deviation of Antigravity Muscles Flexibility Before and After Intervention $(\mathrm{cm})$

\begin{tabular}{|c|c|c|c|}
\hline Group & Before & After & $\boldsymbol{p}$ \\
\hline MAAV & $25.0 \pm 9.7$ & $27.3 \pm 9.0$ & 0.02 \\
\hline EM & $23.6 \pm 8.6$ & $28.6 \pm 7.5$ & 0.000 \\
\hline MN & $27.7 \pm 8.8$ & $31.1 \pm 8.2$ & 0.000 \\
\hline GC & $26.7 \pm 10.1$ & $28.7 \pm 10.7$ & 0.01 \\
\hline
\end{tabular}

in a late manner, as well as rest. However, none of the techniques had the power to modify late the electromyographic activity of the multifidus muscles of the same subjects.

The NM technique proved to be effective in increasing the flexibility of the antigravitational muscles of the subjects of the present study, when the results indicated a statistical difference in the sit-andreach test. According to Butler (10), NM was shown to be effective in increasing flexibility. The technique is capable of generating actions of a mechanical and / or physiological order, favoring the functioning of musculoskeletal structures. NM contributes to axoplasmic flow transit, providing flexibility and better musculotendinous performance, facilitating the good performance of muscle activity [21].

The movements of the body segments increasing and decreasing tension on the neural tissue promote physiological alterations, restoring the normal biomechanics of the nervous tissue and the innervated structures, increasing the electric conduction and raising the electromyographic signal, potentializing the function of all the structures that receive its innervation [10]. In this research, it was possible to notice the increase in the electrical activity of the multifidus muscles after NM, but without statistical difference, both at rest and in isometry.

Jesus [22] observed the effect of the NM technique for the sciatic nerve on the range of motion (ROM) of hip flexion in 50 individuals divided into two groups. Twenty-one of these patients had adverse neural tension reported during the Slump Test and 29 asymptomatic patients without neural impairment. The results showed that in the group with adverse neural tension, ROM increased in $90.47 \%$ of participants (average of $10.09^{\circ}$ ). In the asymptomatic group, ROM increased in $96.55 \%$ of subjects (mean of $11.44^{\circ}$ ). This finding was consistent with the results of the present study, in which $85 \%$ of the subjects submitted to the NM technique increased the flexibility of the antigravial muscles (mean of $3.5 \mathrm{~cm}$ ).

Saminiotto and Fonteque [23] investigated the effect of NM on hip flexion ROM in 10 female, neurologically asymptomatic and non- 
physically active individuals. The technique was applied in extended leg elevation position. The results showed an average increase of $22.5^{\circ}$, concluding that the technique was effective to increase the ROM of this joint, corroborating with the results of the present study.

Lopes [24] performed a study with 39 sedentary individuals between the ages of 18 and 30 years of age, in which the NM technique showed an increase in the myoelectric activity of the vastus lateralis and rectus femoris muscles. However, this result was not statistically significant, corroborating with the results obtained in the present study.

The HVLA technique has local physiological and systemic effects. Among the effects, we highlight the increase in ROM, the reduction of muscle tension and electrical activity, due to the decrease in the electromyographic signal, as well as increased peripheral blood flow [25].

The articular manipulation of the upper cervical region (HVLA) increases the flexibility of the site, as it triggers a relaxing effect contributing to efficient muscle contraction. The joint manipulation technique has proved to be quite effective in increasing the mobility of the musculoskeletal system [26].

Harvey and Descarreux [27] evaluated the growth of the electromyographic signal of the paravertebral musculature of 60 individuals after placement of electrodes in L2 and L5, when the trunk flexion and extension movements were requested soon after vertebral manipulation. These findings diverge from the results found in the present study, because in this the HVLA technique did not significantly alter the electromyographic activity of the multifids. This can be explained by the fact that all participants were asymptomatic. Except for the right multifidus muscles, there was an increase in this electrical activity after HVLA technique, but without statistical significance.

Increased range of motion by joint manipulation may be justified by muscle relaxation and increased joint mobility [28]. In the present study, $70 \%$ of the subjects submitted to the HVLA technique had an increase in flexibility (mean $2.3 \mathrm{~cm})$, with statistical significance $(p<$ 0.05).

Bortolazzo [29] explains that after performing the upper cervical spine (HVLA) manipulation of 5 symptomatic women for a period of five weeks, she was able to increase the electromyographic activity and the activation of the masseter muscle, due to a joint adjustment caused by this maneuver, allowing a readaptation of the body segment, increasing the performance of the myoarticular set.

Zatarantin and Bortolazzo [30] performed a study with 24 asymptomatic women between 18 and 40 years of age, in which they were submitted to bilaterally applied global pelvic joint maneuver (HVLA). However, there was no significant increase in lumbosacral spine mobility after measurement at the Wells Bank and after the Schober test.

Differently from the aforementioned study, Mohseni-Bandpei et al. [31] used lumbar spinal manipulation (HVLA) in individuals with low back pain and observed a significant improvement in lumbar spine ROM, using the Schober test for mobility measurement.

In a study performed with 11 subjects with chronic low back pain, joint manipulations (HVLA) performed in L1 and L2 were performed, the observed effect of which was the increase in muscle flexibility evaluated by the Wells Bank. During the evaluation of the electromyographic signal in the paravertebral musculature, no statistically significant differences were observed [32]. In another study performed with 21 subjects with chronic low back pain, there was an important increase in paravertebral muscle flexibility [33]. In both $[32,33]$, the findings corroborate with the results of the present study.

MET is a neuromuscular technique whose effects affect myoarticular unit. According to Campos and Loza [14], after performing a low intensity isometric muscle contraction, followed by an elongation, the retraction being the state in which the muscle is, a relaxation will be obtained that is the result of the post-isometric autogenic inhibition. The anticipated contraction to the elongation results in a reflex relaxation that accompanies the decrease of the electromyographic activity of the muscle previously in retraction. However, the results found in the present study were not statistically significant to support such an assertion.

Shrier [34] performed a systematic review of five studies on the efficacy of MET on the electromyographic activity of different muscle groups. The post-isometric relaxation period used in the reviewed studies was greater than 1 minute. It was possible to notice that four of these studies found a significant reduction of the electromyographic signal promoted by the technique, differing from the results observed in the present study.

Unlike Shrier's findings, Ferreira [35] performed a MET-based study using a one-minute post-isometric relaxation period, measuring its effect on the electromyographic signal. For this, the sample consisted of 15 women with mean age of 22.6 years, mean body weight of $58 \mathrm{~kg}$, asymptomatic without medication that had an effect on joints and skeletal muscles. The muscles evaluated by the electromyograph were the hamstrings (biceps femoris and semitendinosus). The results showed no significant difference in the electromyographic activity of the muscles evaluated. This corroborates the findings of the present research.

Ferber, Gravelle and Osterning [36] tested MET in physically active and sedentary elders. The technique was performed in two phases of 5 seconds of contraction and 5 seconds of relaxation of the hip flexor muscles. A significant increase in the range of motion and electromyographic signal of the evaluated muscles was observed. These findings corroborate with the results of the present study, in which $95 \%$ of subjects submitted to MET increased the flexibility of antigravitational muscles (mean $5.0 \mathrm{~cm}$ ). However, it diverges in the effect of MET on the electromyographic signal, because in the present study the technique did not significantly alter the electromyographic activity of the multifids.

Rest in dorsal decubitus did not produce any significant late difference in electrical activity of multifidus muscles, but significantly increased the flexibility of antigravitational muscles of the subjects in the control group. This increase on flexibility can be attributed to the relaxation of the antigravitational muscles achieved during the resting period in the supine position.

\section{Conclusion}

The manual techniques discussed in the present study and rest demonstrated a positive late effect on the flexibility of antigravitational muscles in a sample of both sexes and asymptomatic youths, making it possible to increase these conducts to optimize the mobility of limited body segments in the absence of symptoms. The techniques with the highest level of significance for increasing flexibility were the Muscular Energy Technique and Neural Mobilization.

On the other hand, HVLA, MET, NE and rest, as used in the present study, did not produce a statistically significant late effect on 
the electromyographic signal of the multifidus muscles at rest or in isometry in the studied subjects.

The present study had limitations in the selection of subjects that occurred in a heterogeneous way, without grouping individuals of similar age, of the same sex or of the same level of physical activity. In addition, no type of confounding factor was observed, such as physical activity in the interval between the evaluations (before and after the intervention) or even other care that might interfere with the final study result.

New, more robust studies should be encouraged in order to obtain more evidence about the efficacy of similar techniques for modulating electromyographic activity and gaining flexibility, especially in dysfunctional clinical conditions present in disabling pain syndromes. A more homogeneous sample, with screening of groups with common characteristics, as well as adjustments in the execution of the same techniques may contribute even more to the discovery of new outcomes within a theme common to the present study.

\section{References}

1. Gonzales MEB, Zavarce EM. Cinesioterapia. Espanha. Elsevier. 2013.

2. Rodrigues RM, Raimundo CB, Silva KD (2010) Satisfação dos usuários dos serviços privados de Fisioterapia do município de campos dos Goytacazes/RJ. Perspectivas Online 4: 163-180.

3. Block LM (2008) Análise da flexibilidade muscular em idosos. Revista Brasileira de Prescrição e Fisiologia do Exercício 2: 141-148.

4. Gjelsvik B. O Conceito Neurológico Bobath em Adultos. Stuttgart, Thieme. 2008.

5. Borman N, Jackson E, Smith S (2011) Efeito da posição do estiramento no comprimento muscular, amplitude de flexão lombar do movimento, e da curvatura lombar em adultos saudáveis. Fisioterapia Teoria e Prática 27(2):146-154.

6. Ricard F, Sallé J (2010) Tratado de Osteopatia. ( $3^{\text {rd }}$ edn). Editorial Médica Panamericana. Madrid.

7. Oliveira AS (2008) Efeitos do tratamento de quiropraxia sobre pacientes portadoras de espondiloartrose. Jornal Fitnes e Performance 7: 145-150.

8. Macêdo LC (2014) Efeitos da quiropraxia na flexibilidade e mobilidade da coluna vertebral em bailarinas. Revista Brasileira de Ciências em Saúde 10: 118-120.

9. Mansila FPM, Boscá GJJ (2008) Efeito da manipulação atlanto-axoidiana sobre a abertura da boca. Osteopatatía Cientifica 2: 45-51.

10. Butler DS (2003) Mobilização do sistema nervoso. São Paulo: Manole.

11. Astrand PO (2006) Tratado de Fisiologia do Trabalho: bases fisiológicas do exercício. ( $4^{\text {th }}$ edn). Porto Alegre: Artmed.

12. Maia MRA (2010) Avaliação da atividade eletromiográfica do músculo masseter após ajuste de quiropraxia. 2010. 80f. Centro de Ciências Biológicas e da Saúde. Departamento de Fsioterapia. UEPB.

13. Veras LST (2002) Função eletromiográfica, grau de incapacidade e dor em portadores de hanseníase submetidos a tratamento de mobilização neural. Soc Brasileira de Medicina Tropical 45: 83-88.

14. Campos G, Loza E (2001) Técnicas de energiamuscular: princípios e aplicações. Revista Fisioterapia 10: 21-29.

15. Sandoval AEP (2002) Medicina esportiva e ciência aplicada à alta performance e saúde. Caxias do Sul: EDUCS
16. Witvrouw E (2003) Flexibilidade muscular como um fator de risco para desenvolvimento de lesões musculares em jogadores de futebol profissional. Um estudo prospectivo. Jor Medicina do Esporte. 31: 41-46.

17. Grau NSGA (2003) A serviço do esporte: stretching global ativo. São Paulo É Realizações

18. Guedes DP, Guedes JERP (1997) Características dos programas de educação física escolar. Revista Paulista de Educação Física 11: 49-62.

19. Silva Junior RA (2005) A força e a fadiga muscular em indivíduos saudáveis e com dor crônica nas costas: um estudo comparativo de três protocolos de avaliação. Medicina e reabilitação 86: 722-729.

20. Palomari ET (2007) Reprodutibilidade da avaliação eletromiográfica do músculo iliocostal lombar em indivíduos saudáveis: Perspectivas Médicas 8: 45-48.

21. Shacklock M (2005) Aplicação neurodinâmica aperfeiçoada (tensão neural) testes e tratamentos: Uma mensagem para pesquisadores e clínicos. Terapia Manual Escocesa 10: $175-179$.

22. Jesus CP (2004) A mobilização do sistema nervoso e seus efeitos no alongamento da musculatura isquio-tibial. Terapia Manual 2: 162-165.

23. Smaniotto ICG, Fonteque MA (2004) A influência da mobilização do sistema nervoso na amplitude de movimento da flexão do quadril. Revista Terapia Manual 2: 154-157.

24. Lopes RSD (2010) Influência do alongamento muscular e da mobilização neural sobre a força do músculo quadríceps. Conscientiae Saúde 9: 603-609.

25. Brodeur R (1995) A liberação audível associado com manipulação. Jornal da terapia Manipulativa e Fisiológica 18: 155-164.

26. Descarraux M (2004) A eficácia da manipulação da coluna vertebral na prevenção das lombalgias e doenças relacionadas: Estudo comparativo. Jornal da manipulação e terapia fisiológica 27: 509-514.

27. Harvey MP (2013) Modulação a curto prazo das respostas neuromusculares através da manipulação da coluna vertebral: um estudo comparativo. Distúrbios osteomusculares BMC. 14: 92.

28. Herzog WA (2010) biomecânica de manipulação da coluna vertebral. Terapia em movimento 14: 280-286.

29. Bortalozzo GL. Os efeitos imediatos da manipulação cervical alta sobre o sinal eletromiográfico em mulheres com DTM. Jornal Oral Brasileiro 9: 142-332.

30. Zatarin V, Bortolazzo GL (2012) Efeitos da manipulação da articulação sacro-ilíaca e transição lombossacral sobre a flexibilidade da cadeia muscular posterior. Terapias manuais 10: 40-45.

31. Mohseni-Bandpei MA, Critchley J, Staunton T, Richardson B (2006) Um estudo prospectivo, randomizado e controlado de manipulação da coluna vertebral e ultrassom no tratamento da dor lombar crônica. Jornal fisioterapia 92: 34-42.

32. Aguiar LES (2014) Efeito do tempo de mobilização pelo método maitland nas lombalgias. Jornal Reabilitação e Postura 2: 671-692.

33. Piran M, Aily SM, Araújo RO (2012) Análise comparativa do tratamento da dor lombar crônica utilizando-se as técnicas de Maitland, Mulligan e Estabilização Segmentar. Revista Digital 170: 13-15.

34. Shrier I (2004) O alongamento faz melhorar o desempenho? Uma revisão crítica sistemática da literatura. Jornal Clínica Desportiva Médica 14: 267-273.

35. Ferreira OJ, Noronha NMI, Simões BJ (2009) Efeito de três técnicas de alongamento muscular sobre o torque e atividade eletromiográfica. Medicina e Ciência Esportiva do Exercício 11: 125-130.

36. Ferber R, Gravelle DC, Osterning LR (2002) Efeito proprioceptivo de técnicas de facilitação neuromuscular e alongamento em idosos treinados e não treinados. Jornal do Envelhecimento e Atividade Física 10: 132-142.

Copyright: (O2019 Maracaja FK. This is an open-access article distributed under the terms of the Creative Commons Attribution License, which permits unrestricted use, distribution, and reproduction in any medium, provided the original author and source are credited. 